\title{
Ethnic Segregation in Cities: New Forms and Explanations in a Dynamic World
}

\author{
Ronald van Kempen and A. Şule Özüekren
}

[Paper received in final form, August 1997]

Summary. As an introduction to this special issue on ethnic segregation in cities, we offer the readers an overview of the explanatory factors of ethnic segregation and spatial concentration in modern welfare states. After a discussion of the disadvantages and advantages of segregation and concentration, which can be seen as the impetus behind the widespread interest in this topic, we will briefly review some 'traditional' theories. That review will be followed by a closer look at behavioural theories and explanations in which constraints are central. The next section will elaborate on restructuring processes, giving special attention to economic change and its effects on cities, groups and spatial arrangements. We will conclude this introduction with a few remarks on the future of ethnic segregation and concentration and outline some possible directions for future research in this field.

\section{Introduction}

The spatial segregation and concentration of population groups are as old as the hills. They go back at least to $2000 \mathrm{BC}$ or thereabouts, when the city of Babylon was described as being composed of distinct quarters. The outer ones were accessible to everyone; the inner ones, however, were reserved for those in power: kings and priests (Benevolo, 1980). In many medieval cities in Europe, the city centres were inhabited by the well-to-do, while the outer districts were the areas for the poorer segments of the population. According to Engels (1892/ 1980), the European industrial city of the 19 th century had separate territories for the poor, where they could live removed from the sight of the 'happier' classes. Segregation is also clearly visible in colonial cities, where the values of colonial powers are still symbolised in the architecture of the houses and workplaces of those in power and the design of cities and neighbourhoods (see, for example, Hardoy and Satterthwaite, 1989).

Research into segregation and concentration processes is not so very old. Only since the beginning of the present century have researchers tried to deal more or less systematically with these topics. The enormous influence of the Chicago School is well known. Much research into segregation and 
concentration has been focused on immigrants and/or minority groups. The rationale for this focus seems to be a preoccupation in society at large with the idea that the newcomers should be integrated into society. In the same vein, it was felt that segregation and concentration may hinder them in this process.

It is not the aim of this special issue to spell out the effects of concentration and segregation, although we will devote some attention to the implications in this introduction. Rather, this special issue is intended to describe and explain the present state of ethnic segregation and concentration in various countries and cities. Accordingly, the contents of this issue may be highly diverse. But the basic assumption underlying each of the contributions is that the extent and character of ethnic segregation and concentration have changed over the past decades (or years, as the case may be) in different countries. And the main thrust of these papers is that the old list of explanatory factors should be expanded to include new ones.

In this introduction, we will consider various ways to explain segregation and concentration. Our basic standpoint is that any explanation should take a wider perspective than the traditional focus on the choices and constraints of households and individuals. We think that macro-developments must be taken into account. Specifically, developments in the economy and the demography of countries and cities as well as institutional and political developments in these countries and cities should be part of the explanation (see also van Kempen and Özüekren, 1997a). Developments on a macro-spatial level can influence the choices and opportunities of households and individuals (see also Sarre et al., 1989). In other words:

urban problems, including those relating to race and housing, should not be treated in isolation from society at large but are best understood as results of a complex interrelationship between many processes (Sarre et al., 1989, p. 1).

We will start by delineating our basic con- cepts and providing a rationale for research into these topics. The paper is focused on west European welfare states, although we also draw upon some (mainly American) literature on other regions. By narrowing the scope of the overview to these cases, we will not be able to elaborate on the situation in those countries currently in transition in eastern Europe, nor will we be able to discuss the situation in developing countries. Some aspects of this theoretical chapter might be applicable to the conditions prevailing there. However, in the context of this volume, we must focus on the issues at hand. Space does not permit a discursion on the full range of factors pertinent to the explanation of spatial patterns in cities in these regions.

\section{Segregation and Concentration: Defining the Concepts}

Spatial segregation can be seen as the residential separation of groups within a broader population. A group is said to be completely mixed in a spatial sense when its members are distributed uniformly throughout the population. The greater the deviation from a uniform dispersal, the greater the degree of segregation (Johnston et al., 1986). Spatial segregation exists when some areas show an overrepresentation and other areas an underrepresentation of members of a group. The crux of the matter is spatial scale. Spatial segregation may exist between cities and their surrounding areas, between urban neighbourhoods, or even between housing estates within neighbourhoods. Segregation at one spatial level does not automatically imply segregation at another spatial level.

By definition, spatial segregation implies spatial concentration. If an area (neighbourhood) displays an overrepresentation of a certain group (compared to, for example, the share of the group in the city as a whole), we speak of a concentration area for that group. This definition implies that a concentration area may also house many members of other groups. For instance, a single neighbourhood may show an overrepresentation of Turks as well as Moroccans, of Asians as well 
as Pakistani, of the elderly as well as the unemployed, etc.

Both segregation and concentration are defined neutrally, without reference to coercion or choice. Sometimes voluntary segregation is called congregation (van Amersfoort and De Klerk, 1987). A residential mix is defined simply as a situation in which groups of all kinds live together in a residential area. Residentially mixed areas and concentration areas are not diametrically opposed concepts. If a neighbourhood is inhabited by 10 different groups, each accounting for 10 per cent of the total population of that area, we might call it a residentially mixed area. But if all the Chinese of that particular city live in that neighbourhood (as 1 of the 10 groups), it is also a concentration area for the Chinese.

We will not delve into the measurement of segregation and concentration. It is well known from the literature that particular indexes are often used (like the Index of Dissimilarity, the Index of Segregation, the Index of Isolation and the Exposure Index $\left.P^{*}\right)$. These measures have been exhaustively described by many authors (see, for example, Bell, 1954; Duncan and Duncan, 1955; Taueber and Taueber, 1965; Peach, 1975; Lieberson, 1981; Farley, 1984) though also extensively criticised by others (see, for example, Woods, 1976). Despite the critique, most of the indexes are still in use, probably because of the relative ease with which they can be interpreted.

Why, then, is research into segregation and concentration still necessary? One of the main reasons for studying spatial segregation and concentration is that segregation and concentration are considered to be bad or at best temporary problems. First, those who live together do so because they have no other possibilities in the (urban) area. Thus, segregation and concentration reflect their limited choices in the (urban) housing market. Secondly, segregation and concentration may keep them from participating fully in the host society-for example, in the field of employment. Research into segregation and concentration is therefore often explicitly or implicitly based on the premise that this phenomenon should be abolished. Identifying the origins and causes of segregation and concentration may reveal some ways to diminish them. However, segregation and concentration should not always be considered negative or detrimental.

What are the disadvantages of segregation and concentration? And which advantages can be discerned? This section gives a brief overview of the pros and cons of the issues at stake.

\section{Disadvantages and Advantages of Spatial Segregation and Concentration}

\section{Disadvantages}

The literature on spatial segregation tends to emphasise the negative effects it may generate. In the main, the authors suggest that segregation and concentration curtail the opportunities for people to participate in civil society. This restriction comes from a lack of contact with relevant individuals and institutions. Ideas, beliefs and types of behaviour are reinforced by their social milieu (see also Schill, 1992). Morris (1987), for example, poses that spatial concentration of the longterm unemployed may have a devastating effect on their social contacts. In turn, the absence of such contacts may generate inaccessibility to information on the availability of jobs (see also Hughes and Madden, 1991). This also holds for jobs in the informal sector. Households with a high income can generate demand for services that low-income households can provide. This involves housekeeping, odd jobs, cleaning and child care in particular. Spatial separation of these groups may inhibit the contact between those who ask for this kind of work and those who can perform it (Burgers et al., 1997).

Segregation in the school system is mentioned repeatedly in the literature as a disadvantage of the spatial concentration of population groups. It has been shown that children with a foreign background have less chance of receiving a good education if they live in a concentration area. Furthermore, it 
is harder for children living in such areas to become fluent in the majority language (Ballard, 1990). The reason is simple. In a district with a high percentage of immigrant households, most of their playmates will not have a good command of the majority language (see also Özüekren, 1992).

A concentration of poverty can have negative effects on the presence of commercial facilities as well as non-commercial activities (Sarkissian, 1976; Massey and Denton, 1993). This is especially likely when the residents of the area in question are not very capable of standing up for themselves and making their needs known. For instance, they do not know how to get the health care they need, the necessary police protection or adequate schools. Wacquant (1998) refers to their plight as "organizational desertification".

Segregation and concentration can have another effect (Burgers et al., 1997). The residents of concentration districts may have a negative image among the urban populace. That could lead to all kinds of self-fulfilling prophesies. Thus, concentration neighbourhoods can turn into breeding grounds for misery because they are so perceived. As Wacquant puts it, such areas become

isolated territories viewed by both outsiders and insiders as social purgatories, urban hellholes where only the refuse of society would accept to dwell (Wacquant, 1996, p. 125).

Following Sennett (1970), Goldsmith (1997) points out that segregation can lead to a lack of empathy for those who reside in another area. Furthermore, it can lead to an inadequate and superficial understanding, based on the newspapers, hearsay or television reports. And ignorance often begets intolerance and fear.

When discussing the disadvantages of segregation, we must briefly address the urban ghetto and the 'underclass'. Johnston et al., (1986) define the ghetto as a residential district that is almost exclusively the preserve of one ethnic or cultural group. Van Amersfoort (1980) applies a stricter definition: a ghetto is an "institutionalized" residential area in which all the inhabitants belong to a single ethnically, racially or religiously defined group and all the members of this group live in this area (they do not live in other areas). "Institutionalized" means that the inhabitants did not choose their dwelling or residential area themselves: they were to some degree coerced by society. ${ }^{1}$

In the light of these commentaries, it should by now be clear that we should not consider every area that is inhabited by an ethnically, racially or religiously defined group as a ghetto (as in Forman, 1971). The involuntary aspect is a very important dimension. In the words of Ceri Peach:

the black ghetto is not just a voluntaristic temporary phenomenon (Peach, 1992, p. 131).

According to Kenneth Clark (1965), the existence of the ghetto is the consequence of a deliberate policy of those who wield power in mainstream society:

The dark ghetto's invisible walls have been erected by the white society, by those who have power, both to confine those who have no power and to perpetuate their powerlessness (Clark, 1965, p. 11).

Without the element of coercion, the ghetto may be more appropriately described as an ethnic enclave (Marcuse, 1997).

Wacquant and Wilson (1993) have made a distinction between the organised ghetto of yesteryear and the hyperghetto of today. In the hyperghetto, activities are no longer structured around an internal and relatively autonomous social space that duplicates the institutional structure of the larger society and provides basic minimal resources for social mobility. Living in the hyperghetto is living outside mainstream society. Especially in a situation like this, immigrants might be thrown back on each other's company, resulting in cultural 'fossilisation' (the continuance of the lifestyle they had in the home country) or even radicalisation (see, for example, Özüekren, 1992). 
The disadvantages of spatial concentration are expounded in the literature in which the "underclass"' is combined with the ghetto (see Wilson, 1987). ${ }^{3}$ At present, it seems impossible to give a single definition of the underclass. Nonetheless, there seems to be a consensus that members of the underclass suffer from prolonged labour-market marginality and have virtually no chances to alter this situation, even across generations. They display deviant or illegal behaviour like gambling, drug abuse, crime, teenage pregnancy and dropping out of school. They are economically and politically isolated. Their lifestyle, often a matter of survival, differs from that of the other poor. Because their lifestyle differs from that of mainstream society, they find it hard to take part in that society (see, for example, Wilson, 1987; Hughes, 1989; Warf, 1989; Kasarda, 1990; Gallie, 1994). Wilson (1987) uses the term "ghetto underclass". He argues that the concentrated poverty of the ghetto generates problems that differ in size and kind from the problems the poor face in other environments (see also Sheppard, 1990).

The concept of the underclass has come under heavy attack. In our opinion, it is surprising that the term is still in use after Gans (1990) advanced his convincing argument to drop the term altogether. One of the most pernicious aspects of the term is its power as a buzzword (which is obviously why the term is still used). Other dangers lurk in the term's flexible character and, most importantly, its use as a container concept to lump together different population categories like the unemployed, the homeless, teenage mothers, drug users and drug dealers without adequately considering their particular characteristics. This aggregation (or synthesising) can have negative consequences on the formulation of social policy (Gans, 1990). Other authors have also attacked the use of the term 'underclass' on different grounds (see, for example, Jencks, 1992; Morris, 1993; Fainstein, 1993). Wilson (1991) started to use the term 'ghetto poor' instead, calling for more research and less fixation on labels.

\section{Advantages}

The existence, development and nurturing of social contacts - which are made possible by the physical proximity of like-minded people_can be seen as an extremely useful aspect of spatial segregation and concentration. Social contacts can lead to the emergence and preservation of a culture that is not based on the norms and values of mainstream society but on those of a specific group. The effort to maintain a minority culture entails more than particularistic attitudes and behaviour. It is also manifest in the persistence of shops, clubs and religious institutions (Peach and Smith, 1981).

The key to understanding minority cultures lies in the concept of social networks. Through their networks, people are able to derive benefit from each other and offer one another support (see also Portes and Sensenbrenner, 1993). The interaction may take diverse forms, ranging from a pleasant conversation over a cup of coffee to using a neighbour's washing machine or freezer, all the way to borrowing money at low (or no) interest, or occupying a room for a short or long period (as in the case of the undocumented immigrants; see Burgers in this issue). Incidentally, not all members of the group will necessarily appreciate the closeknit ties. Wacquant (1996, p. 126) warns that "One must be careful not to romanticize conditions in the proletarian neighborhoods and segregated enclaves of yesteryear".

More advantages can be found in the literature on ethnic entrepreneurs (see also Burgers et al., 1997). There, too, networks are important. Concentration of an ethnic group makes it easier to maintain ethnic networks. Sometimes, those networks give ethnic enterprises a competitive edge over other businesses. For instance, networks allow ethnic entrepreneurs to find loyal and flexible employees quickly within their own group (Wilson and Portes, 1981) or even within their families (Sanders and Nee, 1996). In this manner, newly arrived immigrants can gain the experience and knowledge they would eventually need to start their own 
business in the future (Bailey and Waldinger, 1991). Especially when few opportunities are available on the formal labour market, ethnic enterprise can provide a channel for social improvement (Portes and Zhou, 1996). All in all, spatial segregation and concentration may offer some advantages:

Segregated and tightly clustered ethnic neighbourhoods support cultural exclusiveness by fostering close social contact between group members and by acting as protective spaces ... (Aldrich et al., 1981, p. 175).

The result may be social exclusion from mainstream society but certainly not from their own group:

By joining the ethnic cluster, members of a particular group reduce their isolation, and the existence of the group itself within a clearly defined area enables an organised defence to be developed (Boal, 1981, p. 235).

A residential mix can be seen as the opposite of spatial concentration. A residential mix is not necessarily better than concentration, nor does it automatically mean improvement. A residential mix may also be a transitory stage from one pattern of concentration to another. This is what Clark (1996) suspects to be happening at present in Los Angeles. Later in this special issue, van Kempen and van Weesep will address some specific disadvantages of a mixture of different ethnic groups.

\section{Explanations of Concentration and Segre- gation}

In explaining patterns and processes of spatial concentration and segregation, three 'traditional' approaches can be discerned: the human ecology approach, social area analysis and factorial ecology. Good descriptions of these approaches have already been made (see, for example, Bassett and Short, 1980; Sarre et al., 1989). Therefore, we will only give a brief overview here.

These traditional approaches did not assign the individual a key role. In that light, the behavioural approach - in which acts and intentions of individuals were central-can be seen as a logical sequel to earlier approaches. The ethnic-cultural approach is an adaptation of the behavioural approach. Special attention was given to the role of constraints on the housing markets and resources of individuals in the more (neo-) Marxist-oriented analyses and (neo-) Weberian ideas. The role of government-and consequently the role of institutional discrimination-lay at the core of managerialist approaches. The key elements of all these approaches will be summarised below. The overview will conclude with a section on the role of macro-developments as they manifest themselves in specific countries and cities.

Explanations of segregation and concentration overlap with the explanatory factors of housing choice. This is not surprising when the same types of housing are located in the same areas. Normally, this is the case in cities. Or, to put it another way, urban neighbourhoods and districts are hardly ever characterised by a complete mixture of housing types in terms of price, age and size, and tenure. Therefore, a concentration of housing types almost automatically implies a concentration in specific areas.

\section{'Traditional' Approaches}

The human ecology approach. The structural analysis of neighbourhood change, residential differentiation and the concomitant processes of spatial segregation and concentration started with the human ecology tradition associated with the Chicago School (see, for example, McKenzie, 1925/1974; Burgess, 1925/1974; Park et al., 1925/1974). Human ecologists analysed the city as a separate entity and were less concerned with the city as a reflection and manifestation of the wider society (Bassett and Short, 1980). The city developed through a competition for space to produce concentric zones (Burgess, 1925/1974), specific sectors (Hoyt, 1939) or multiple nuclei (Harris and Ullman, 1945), housing households with different resources and other characteristics. Processes of 
invasion and succession involved a chain reaction, with each preceding immigrant wave moving outwards and being succeeded by more recent, poorer immigrants (Park et al., 1925/1974). The final pattern of segregation, the "mosaic of social worlds" (or a residential mosaic; see Timms, 1971) was seen as a 'natural' equilibrium. It was a consequence of various processes: invasion, dominance and succession. Behind it was the idea of immigrant enclaves as transitional stages on the road to eventual acceptance and integration in the larger (American) society (Clark, 1996, p. 110).

It is argued that the social ecologists paid too little attention to how neighbourhood change actually occurs. Their explanations were insufficiently informed by empirical research referring to choice, preference and social action (for example, Hollingshead, 1947). Moreover, their neglect of the influence of institutional and political factors rendered their account unsatisfactory, even for cities where state intervention through planning and housing provision was limited (Bassett and Short, 1989). For countries and cities where the role of the state has strongly influenced patterns of urban growth and residential developments, their approach was even more inadequate. The ideas of the Chicago School were essentially American, and maybe even 'Chicagoan'. They were developed in a specific time-period and under a specific system: the free market economy, in which terms such as social security and housing subsidies were not common. Therefore, the applicability of these ideas in the European situation was questioned. Moreover, the classical formulation of human ecology was criticised for being derived from a biological model, rather than being based on cultural and social processes (Wirth, 1944; Firey, 1947; Jones, 1960). As Bell puts it:

... the early Chicago ecologists' view of the city has been revised, and we now know that it gave a one-sided and partially false picture of the nature of urban life in its exaggerated portrayal of personal and social disorganization and its adherence to the notion of natural forces as the prime movers of the emerging city (Bell, 1968, p. 136).

Despite the critique, the ideas of the human ecologists have stimulated much research. Some of the studies that have come out of the Chicago School are now considered classics in their field. These include Harvey W. Zorbaugh's The Gold Coast and the Slum (1929), Louis Wirth's The Ghetto (1928) and, of course, The City, edited by Park, Burgess and McKenzie (1925). Also, the approach associated with the Chicago School has resulted in empirical studies that were sensitive to spatial variations and sympathetic to local conditions (Bassett and Short, 1980). Moreover, hypotheses advanced by the Chicago School are still referred to and even being tested in empirical situations (with reference to the city of Rotterdam in the Netherlands, see de Jong and Verkuyten, 1996). However, testing these hypothesesthat is, checking whether or not the populations of neighbourhoods change in the ways the ecologists described-is only useful if the mechanisms behind them are also clear. The explanatory concepts used by the classical ecologists are not suited to present-day analysis (see Denton and Massey, 1991). In particular, they do not apply to cities in west European welfare states.

Social area analysis and factorial ecology. The human ecology approach was followed by positivistic-empirical approaches like deductive social area analysis (for example, Shevky and Williams, 1949; Bell, 1953; Shevky and Bell, 1955) and inductive factorial ecology (for example, Murdie, 1969; Robson, 1969; Berry and Kasarda, 1977). Factorial ecology uncovered the socio-spatial layout of many cities in the world, though without focusing on causality (de Decker, 1985). Census variables were selected and "run through the statistical mill of principal components analysis or factor analysis" (Bassett and Short, 1980). Many analyses revealed sectoral and zonal patterns. Differ- 
ences between urban neighbourhoods could often (but not always; see Robson, 1969) be summarised by three sets of variables: socioeconomic status, family status and ethnicity (Bell, 1968).

Critics of social area analysis and factorial ecology said it was descriptive and based on very meagre theoretical notions (Kesteloot, 1980; Bassett and Short, 1989; Yeates, 1989). Other critics pointed out that since most of the research had been done in the US, the results should not be applied automatically to the European situation (see O'Loughlin, 1987). Finally, the subject was seen as homo economicus: a fully informed individual with a perfect ability to act in an economically rational way (see Bolt and van Kempen, 1997).

\section{The Behavioural Approach}

Explanations that explicitly include the preferences, perceptions and decision-making of the individual in housing and residential mobility were introduced in the behavioural approach. This can be seen as a reaction to the spatial analysis approach. The behavioural approach does not necessarily focus on the behaviour of members of minority ethnic groups, of course.

Behavioural models focus on the demand side of the housing market. One of the most famous models, the one formulated by Brown and Moore (1970), took place utility as the central concept (Wolpert, 1965). Place utility can be seen as the level of satisfaction or dissatisfaction with a certain location or dwelling. A discrepancy between the actual situation and one's aspiration might lead to a decision to move. But before any such decision is made, a certain 'threshold' should be reached; not every feeling of dissatisfaction leads to a decision to move. Hooimeijer and Linde (1988) add that a decision to move is not always motivated by this discrepancy. The decision might be based on the idea of taking advantage of an opportunity (which may suddenly become available) to improve the housing situation, even though the household had not been very dis- satisfied. In other words, push and pull factors play a role. Consequently, households generally move to better situations: a larger dwelling, a quieter neighbourhood, a better location with regard to the workplace, etc.

In behavioural approaches, choices of households are directly linked to positions and events in the family life-cycle (see, for example, Clark and Dieleman, 1996; Clark et al., 1997). Household characteristics are major determinants of housing (and locational) preferences (Adams and Gilder, 1976; Clark et al., 1986). The age of the head of the household and the household composition are the two essential characteristics. Younger people generally have different preferences from those of middle-aged people, and smaller households usually have a different set of preferences in comparison with larger households. Age intersects with the household formation cycle: establishing a durable relationship, starting a family (children are born), contraction of the family (children leave home), and the death of a partner. These are all situations that influence the household's size and its preferred type of dwelling (Rossi, 1955; Speare et al., 1975; Stapleton, 1980). Preferences are often expressed in terms of floorspace and/or the number of rooms in the dwelling. Large and growing households generally want larger dwellings than small and declining households.

Different groups, even different households, have divergent ideas of what constitutes a desirable housing situation. In fact, each household has its own 'subjective hierarchy'. The peak of the housing career for one household might be to live in an apartment. Another household might attach great importance to living on the ground floor in a house with a garden, in order to meet its own requirements for everyday living. For still another household, the type of dwelling might not be important at all. Instead, the distance to work or school might be the crucial dimension of quality.

Innumerable large and small research projects of the behavioural type have now been carried out in the field of housing demand, residential mobility, locational prefer- 
ence, and satisfaction or dissatisfaction with the dwelling and the neighbourhood. The relation with the development of the neighbourhood and processes of segregation is not always clear, nor is it always the primary aim of these studies. However, in any effort to come to grips with the position of a neighbourhood, we believe that the opinion of the inhabitants themselves is an essential ingredient. To define a concentration area of minorities as a bad place to live, for example, is poor scholarship if it ignores the opinions of the inhabitants themselves, the position of the neighbourhood in their daily lives and their housing careers (Bolt and van Kempen, 1997).

The behavioural approach has been criticised for its emphasis on demand and the concomitant lack of attention on constraints (see, for example, Hamnett and Randolph, 1988). Neither the supply of dwellings nor their accessibility (allocation procedures) gets much attention. Although this might be true in general, several behavioural studies have incorporated institutional variables or other constraints.

The reality of all choices is that they are made under conditions of constraint (Cross, 1992, p. 91).

Or in the words of Ceri Peach:

While the 'constraint school' did not recognise choice, the 'choice' school was keenly aware of constraint (Peach, 1991, p. 73).

The ethnic-cultural approach. The ethniccultural approach can be seen as a special form of the behavioural approach. The general argument within the ethnic-cultural approach runs thus: housing conditions and residential patterns differ between groups, and these differences can be attributed to cultural differences between these groups. There is a clear element of 'choice' in this approach. In this vein, Clark (1992) states that whites and Asians have stronger preferences for neighbourhoods populated by their own race than do Hispanics and blacks and that this is one of the main explanations for their different settlement patterns. Robinson (1981) depicts differences in housing situations between Asian and West Indian groups and explains these differences by different cultural orientations. She states that the overwhelming majority of Asians in Britain are still inspired by the 'myth of return'. Therefore, they are not interested in assimilation into British society.

The ethnic-cultural approach allows for the inclusion of constraints in the explanation. The choice for owner-occupied dwellings can be seen as a cultural preference, but also as a defensive reaction against racist practices of landlords (see, for example, Cater and Jones, 1987; Bowes et al., 1990). This approach concedes that differences within groups may be just as important as differences between groups. The ethniccultural approach opens our eyes to the fact that Asians, Turks, Moroccans and West Indians - to mention just a few of the backgrounds of immigrants in west European countries-are not single groups with unitary values. All kinds of sub-groups might attach different meanings to many aspects of life, including the kind of housing and neighbourhood in which they would like to live (see, for example, Ballard, 1990).

\section{Constraints and Resources}

There has been extensive debate on the importance that should be attached to elements of choice and factors of constraint. The authors who adhere to the behavioural and ethnic-cultural approach focus mainly on the preferences of the (ethnic) household and individual (and therefore on the demand side of the housing market). Other authors tend to focus on the constraints households face and the resources they use to overcome these constraints. In the latter view, the structure of the supply of dwellings - which includes the factor of accessibility-determines the social and spatial layout of the city. In this section, we will briefly review the standpoints of the (neo-) Marxist School and the (neo-) Weberian School. We will also elaborate on the 
different resources of individuals and households.

\section{Marxists and Neo-Marxists}

According to the (traditional) Marxists, the capitalist economy revolves around production. The allocation of housing is a secondary issue. Also, Marxist analyses of ethnic minorities in general and their segregation and concentration patterns in particular are rare. Social class is the major social division, while racial and ethnic divisions are not regarded as major social cleavages (see Sarre et al., 1989, pp. 21-22; Castles and Kosack, 1973; Harris, 1984).

Van Amersfoort (1982) has argued that it is impossible to apply the classical Marxist notion of class to immigrant groups in western Europe. According to Sarre et al. (1989, pp. 23-24), Marxists have failed to provide a convincing argument for the supremacy of class over other factors such as race. Social class alone cannot provide a satisfactory explanation of the pattern of residence of ethnic groups (see, for example, Peach, 1981). Moreover, the Marxist approach:

... conveniently ignores distinctions of religion, culture, ethnicity, origin, and return orientation of immigrants that are independent of their general working-class status. More importantly, it ignores the process of choice by which households distribute themselves within areas dominated by the same social class (O'Loughlin, 1987, p. 59; see also: Peach, 1992, p. 134).

On the other hand, Marxists have helped researchers to look at broad (economic) developments in society:

... the Marxist perspective has helped to clarify the structural components of the racial inequalities we have observed. On the one hand, it has highlighted the wider structural forces within economy and society, of which the housing market is a small subset. On the other, it has provided a reminder that racial cleavages and dis- crimination reflect but one form of structural inequality in a basically inegalitarian society (Sarre et al., 1989, p. 25).

\section{A Neo-Weberian Perspective: Housing Classes}

Rex and Moore's Race, Community and Conflict (1967) can be seen as the beginning of the neo-Weberian or institutional approach in housing research. Their concept of 'housing classes' has sparked an enormous discussion. It is grounded in the idea that housing, and especially desirable housing, is a scarce resource and that different groups are differentially placed with regard to access to these dwellings. People are distinguished from one another by their strength in the housing market (Rex, 1968).

The main criticism of this approach focused on the implied unitary scale of values of different housing consumers and the unclear basis of the conflict between the classes (see, for example, Haddon, 1970; Dahya, 1974; Pah1, 1975; Saunders, 1979; Sarre et al., 1989). But on the other hand, Rex and Moore's study has aroused interest in housing as a scarce commodity. Consequently, many studies have focused on the issue of access to housing. Different resources of households can be identified. Housing classes may still be useful in studies of specific population groups (such as immigrants). Like housing classes, immigrants can be seen as groups of households with a common set of preferences and constraints linking them to a common housing type (White, 1987) and to specific neighbourhoods.

\section{Resources of Households}

Both the Marxist and the neo-Weberian approach emphasised the importance of the resources people have. These resources determine the 'strength' of households in the housing market (see also Rex, 1968; Siksiö and Borgegård, 1990). Resources can take various forms. Financial resources refer to income, security of income and capital assets. Cognitive resources include education, 
skills and knowledge of the housing market. Political resources refer to the political power people wield, either formally or informally. And social resources refer to the contacts people have, which may help them to find suitable housing and places to live (see also Bourdieu, 1979). Even the present housing situation can be seen as a resource. All these resources are highly influential in explaining the housing-market positions of households. From all the papers in this issue, this again becomes very clear.

Financial resources. In any market, purchasing power, resources and opportunities are unequally distributed. In market societies, freedom of choice is closely tied to power and resources. In this context, the key to freedom is an individual's labour-market position. People with a relatively good labour-market position are better poised to take an advantageous position in other markets, including the housing market. And those with a weak position in the labour market generally have a weak position in the housing market (Rex and Tomlinson, 1979). Theoretically, it might be expected that lowincome households will live in worse housing conditions than households with higher incomes. Spatially, this means that higher-income households will generally have more options available to them (see also the paper by White in this issue). Therefore, it might be expected that higher-income households will be more dispersed. Bhardwaj and Rao (1990) attribute the different spatial distributions of Asians in Britain and the US to such differences. In the US, many Asian Indians belong to the category of managers and professionals. They tend to have fairly good incomes and thus have a wide choice of residential locations. This contrasts with the situation in Britain. There, many Asian Indians entered the country in response to demand at the bottom of the occupational structure (see also Peach, 1984; Robinson, 1986). Alongside income, Bhardwaj and Rao (1990) also point out the importance of other factors, like the availability of mortgages and the fact that Indians in Britain were former subjects of the Commonwealth.

In addition to the level of income, income security is also important to a household's possibilities on the housing market (Rex, 1968). Income security can be a major factor when the household is thinking about buying a home. Access to owner-occupied housing is easier for persons with incomes that are both stable and high. Lending institutions usually run a check on the creditworthiness of prospective buyers. To become a homeowner may therefore be more difficult for immigrants, whose incomes are generally low due to their skill levels.

Finally, the availability of capital assets might be very important to the housing-market position of households. Sometimes, children of home-owners may buy a dwelling with a downpayment consisting of a part of the equity built up by their parents (Forrest and Williams, 1984).

It would seem that a household's financial resources would be closely related to its housing conditions and housing-market position. (That is, people with the lowest incomes may be expected to live in the worst housing.) Nevertheless, this relationship may be expected to change in some west $\mathrm{Eu}$ ropean welfare states. These countries intervened in their housing markets after World War II. They established a wide range of social programmes, including rent control and a variety of subsidies (Lundqvist, 1992). In addition, almost all west European countries created a social rented housing sector (we will return to this later).

Cognitive resources. Knowledge of the local housing market is an important cognitive resource. It might enable one to reach a desired housing situation in the housing market. For example, people who are not proficient in the language may not understand allocation rules. Others can deal with the rules and apply them to their own benefit. Smith (1977), for example, concluded that many Asian immigrants in Britain did not know that council housing existed, even after living in the country for 12 years. A similar 
example comes from Sweden, where Özüekren (1992) showed that none of the Turkish interviewees in a Stockholm suburb knew that private rental flats existed there. Of course, knowledge can be increased by providing adequate information (see Huff, 1986).

Education is the most important cognitive resource. It is critical to the position an individual may attain on the labour market. However, a high level of education is not automatically related to a high income. Nor does a low level of education automatically imply a low wage. People with little education may have learned a craft or may have skills with which they can earn a lot of money, legally or otherwise (in the informal sector).

The housing career itself may also prove to be an important cognitive resource. To have had a housing career might help one understand how the housing market operates. This is particularly applicable to immigrants who come from countries where different rules and regulations apply (Özüekren, 1992).

Political resources. Political resources reflect the possibility of attaining and defending formal rights in society. Formal rights may hinder people or enable them in their efforts to achieve important aims in life. In the case of immigrants, discrimination may have a direct effect on political resources. Not having the formal right to participate in society and not having access to certain positions in the labour market and the housing market can strongly affect individuals' and households' ultimate housing conditions. Giffinger and Reeger (1997), for example, note that foreigners in Austria have no access to public housing. Moreover, they have no right to some forms of household-related allowances. Although they do have formal access to newly built housing, the fact that they are not eligible for housing allowances makes access to these dwellings very difficult. Discrimination in the housing market has been demonstrated in many different ways in many places (see, for example, Farley (1995) on the rented sector in the St Louis area). This might have a direct influence of the pattern of segregation and concentration.

Social resources. The concept of social resources, or social capital, refers to the direct or indirect accessibility of 'important' persons or groups and the membership of social networks (Wippler, 1990). These social networks can have important functions in social integration, in society as a whole, or within sub-groups (see also Friedrichs' paper in this issue). They can also help people to find solutions in significant areas of life, to achieve important aims and to attain positions in the labour market and the housing market. The role of information is crucial in this respect. Dahya's research in Bradford has demonstrated that the concentration of Pakistani in certain neighbourhoods can largely be explained with reference to networks of fellow countrymen (Dahya, 1974).

Present housing conditions. Finally, present housing conditions can be a key resource for the future housing situation. This is clear with regard to the ownership of a house, but it can relate to rental dwellings as well. In some housing markets, the inhabitants of certain types of rental units have allocation priority for other dwellings. In other cases, a more desirable housing situation can be obtained by swapping rented dwellings.

\section{The Role of the Government, '(Urban) Managers' and Institutional Discrimi- nation}

Both the behavioural and the ethnic-cultural approaches focus on the individual or household as the relevant actor. In the previous section, we emphasised the importance of various kinds of resources at the household and individual level. Essentially, all these aspects are related to the demand side of the housing market. A focus on the supply side of housing includes the role of governments as institutions and the role of individuals within these institutions.

In many west European countries, the state 
has had a strong influence on housing markets. Especially in countries like the Netherlands and Sweden, the number of social rented dwellings has been very important in the supply of housing. By providing social rented dwellings, the state ensures that lowincome households have the opportunity to live in decent housing. In other countriesfor example, in the UK - the social rented sector has either been declining very rapidly (Meusen and van Kempen, 1995; Murie and Musterd, 1996) or has never been very large (as in Belgium; see Kesteloot et al., 1997, and Kesteloot and Cortie in this issue). In a retreating welfare state, the number of affordable rented dwellings will almost inevitably decline, especially in the newly built stock. This is exactly what has happened in most west European countries since the second half of the 1980s (Özüekren and van Kempen, 1997).

The retreat of the welfare state has an obvious effect on the income position of households of all kinds. When governments pursue a policy of cutting budgets, everyone who depends on the state (pensioners, the unemployed, the handicapped, etc.) will inevitably feel the pinch. The austerity programme may lead to lower subsidies for housing. Consequently, fewer affordable dwellings might be built or less maintenance may be done on the existing stock. More generally, transforming housing markets may alter the opportunities for all kinds of groups, including immigrants (see, for example, Kemper's paper about Berlin in this issue).

The supply of housing can be a direct effect of political decisions. In Britain, for example, the promotion of home-ownership under the 'Right to Buy' led to the heavily subsidised sell-off of council housing. But it also led to strict controls on the production of council houses as well as to higher rents (Phillips and Karn, 1992). It is well known from the British housing literature that not everybody profits from the sale of council houses. In particular, the impact on the housing of black households has been highlighted (Mullings, 1992).

Local government or housing associations might decide to allocate dwellings in a certain neighbourhood exclusively to non-immigrants. Housing associations can subtly refuse to register immigrant families by saying that no large dwellings are currently vacant or by asking high registration fees (van Kempen and van Weesep, 1991). The crucial role of these and other 'managers' is stressed in the work of Pahl $(1975,1977)$ and Lipsky (1980). These authors examine the role of the housing officer in the allocation of resources. Pahl suggests that social gatekeepers (like housing officers) can allocate resources according to their own implicit goals, values, assumptions and ideologies. This means that stereotypes and racism might influence their decisions (Tomlins, 1997).

Setting a quota is a negative allocation procedure. Under a quota, no more than a certain percentage of immigrants are allowed to live in a given neighbourhood or block of houses. In France, for example, HLM organisations have a one-for-one rule. In other words, they only house an ethnic minority applicant in an estate when another ethnic minority household is leaving (Blanc, 1993). It is even easier for private owners to discriminate. As a result, when rental units are unavailable or inaccessible, households may be more or less forced to buy a sub-standard dwelling (van Hoorn and van Ginkel, 1986). Owning property may well be the housing choice of last resort. This is clearly the case where rental housing is scarce or inaccessible because of bureaucratic procedures or discrimination (van Weesep, 1984).

Discrimination, both direct and indirect, also exists in the private rented sector. Discriminatory practices may be encountered among private landlords as well as among the intermediaries between landlords and prospective buyers or tenants. For instance, landlords might offer a vacancy to a friend or acquaintance rather than rent it to an ethnicminority household. Also, landlords can place restrictions on prospective tenants, and rental agents may classify the applicants accordingly (see, for example, Karn, 1983). Studies in the US have shown that real estate agents are primary information brokers and 
major agents of change (see, for example, Galster et al., 1987; Turner and Wienk, 1993). According to Teixeira:

They accelerate, decelerate, and prevent neighborhood change, particularly in racially segregated areas of U.S. cities (...) Racial and ethnic steering by real estate agents not only limits the ability of minority groups to exercise neighborhood choice, but also contributes to the perpetuation of residential segregation patterns in major American cities (Teixeira, 1995, p. 176).

Exclusionary policies of local authorities and private landlords may force ethnic minorities into owner-occupation, even, or especially, in an early stage of their housing careers (Phillips and Karn, 1992). Some neighbourhoods may thereby become virtually closed to them, forcing them into areas where accessible housing is available (see, for example, Ward and Sims, 1981; van Hoorn and van Ginkel, 1986). Discriminatory practices may also exist in the owner-occupied sector. An estate agent may fear that selling a house to immigrants would lead to lower prices in the neighbourhood. Kemeny (1987) reports that some estate agents in the US deliberately sell to blacks in order to create a chain reaction of sales by whites at knock-down prices. This approach can be very profitable to the estate agent.

In the event of a declining supply, rules may be more influential. Rules, however, are subject to interpretation; for example, they are interpreted by officers who are responsible for the allocation of housing or money. These officers may find themselves torn between all kinds of ideas and pressures that originate from the management board, the housing consumers, colleagues and, of course, from their own preferences (see, for example, Karn, 1983; Tomlins, 1997).

\section{Introducing Macro-developments: The Influence of the Context}

It is not a very new idea that cities are part of a larger society:
... cities are the central elements in the spatial organization of regional, national, and supranational socioeconomies by virtue of the interregional organization in a total 'ecological field' of the functions they perform (Berry and Kasarda, 1977, p. 85).

Thus, there is no space privileged in advance, in functional terms; space is defined and redefined according to the conjuncture of the social dynamic (Castells, 1977, p. 179).

Because of this interrelatedness, areas within the city are also influenced by developments and decisions on higher spatial levels. Many sociologists and geographers now agree that patterns of segregation and concentration change as a consequence of individual household decisions in response to the complex interaction of a variety of structures and developments on different spatial levels. General processes-like economic restructuring at a global level - have their impact on local situations and developments (Sassen, 1990; Burgers and Engbersen, 1996) and on choice patterns of households (Clark et al., 1997, p. 18).

Households operate within the societal, demographic, economic and political context of their countries, regions and cities. The competition between households and individuals in the housing market (as well as in other markets) may result from changing ideas on the part of an individual or household. Those changes, in turn, may be caused by changes in local structures. But they may even be related to changes at a national or transnational level. Therefore, a contextual approach is needed. In order to explain (spatial) changes at the local level, we have to incorporate structures and developments at other spatial levels (see also Sarre et al., 1989; Karn et al., 1985). In the words of Phillips and Karn, we should be aware of:

... a close and dynamic relationship between individual strategies, institutional behaviour and the wider social, economic and political structure, as housing pur- 
chases and institutions respond to each other within a framework of local and national change (Phillips and Karn, 1992, p. 358; see also Clark and Dieleman, 1996, p. 137).

Housing conditions are basically the result of the interrelation between resources of households, preferences of households and the availability and accessibility of dwellings. This interaction does not take place in a vacuum. It occurs in a context of economic, demographic and political structures (including the changes in the welfare state). And that context may differ from one country to the next, sometimes even between regions within countries. Moreover, these elements may change through time. Seen in this way, the locational differences and historical developments set the stage for the current housing conditions of all households that operate within a housing market. Therefore, a study of (individual) housing conditions and housing-market positions should start with an analysis of (aggregate) contextual developments. ${ }^{4}$

\section{Economic Developments}

The global restructuring of the economy ${ }^{5}$ and the consequent transfer of manufacturing to newly industrialising nations leads to higher unemployment among manual workers in west European countries. The post-industrial transformation of the economy in the late 20 th century has affected the economic backbone of the cities: the traditional goods-processing industries. These industries in particular provided entry-level employment opportunities for the lesser skilled (Kasarda, 1993), among them the immigrants. Because of the transformation, employment opportunities in these industries are being decimated. As a result, immigrants' household incomes tend to decline, which limits their possibilities of neighbourhood choice (Özüekren and van Kempen, 1997). Bailey and Waldinger (1991, p. 43) mention that the impact of the post-industrial transformation of cities on their minority populations is a central issue in urban research. However, Cross (1992, p. 112) notes that despite the growing interest in labour-market change, including the decline in manufacturing, the growth of services, the spatial reorganisation of production and the increasing feminisation and casualisation of the labour force, it is very striking that the analyses of the research community have often only assumed implications for minorities.

Eversley (1992) points to an interesting relationship between economic development and immigration. Economically expanding regions tend to attract migrants. In Britain, individuals born in the New Commonwealth and Pakistan (NCWP) were initially concentrated in districts that were economically flourishing. There, jobs were available in low-pay industries, which were not attractive to the British-born. This implies that areas already suffering from high unemployment levels did not attract NCWP migrants. The economic well-being of a region thus seems to be important as a pull factor. Migrants gravitate to places that offer them the greatest opportunities in terms of both jobs and housing. Chain migration may then add to the number of migrants in a region (Sarre et al., 1989, pp. 6-7).

The relation between economic developments on the one hand and spatial concentration and segregation on the other is elaborated in two theses. One is known as the mismatch thesis, and the other is called the polarisation thesis.

Mismatch thesis. Among other researchers (like Kasarda et al., 1992), Wilson is one of the main proponents of the mismatch thesis. He advanced this thesis in his influential and highly acclaimed - though much criticisedbook called The Truly Disadvantaged (1987). The mismatch hypothesis has been succinctly summarised by Bailey and Waldinger:

In general terms, the mismatch hypothesis suggests that the increase in the educational and skill demands of the urban economy have outstripped the skills of an 
increasingly large segment of the urban population. Thus, minority populations that have traditionally relied on lowskilled employment will no longer have this access to the urban job market (Bailey and Waldinger, 1991, p. 44; see also Schill, 1992).

This mismatch hypothesis has also been used, implicitly or explicitly, in studies among the former guest workers in western Europe. They too have suffered from the changing economy and the decline in lowskilled jobs. They too have been left unemployed and consequently with low incomes-see, for example, for Belgium, Kesteloot et al., (1997); for the Netherlands, van Kempen and van Weesep (1997); for Germany, Glebe (1997); and for France, Blanc (1993). Because of their low incomes, they are unable to move to other (higherstatus) areas. They are confined to areas with low rents and often-but not always (see, for example, Özüekren and Magnusson (1997) for Sweden)-low-quality housing.

The mismatch hypothesis has been used as a point of departure in many research activities. But its validity has not always been demonstrated. In their recent book on Los Angeles, Waldinger and Bozorgmehr (1996) contend that the whole debate on mismatch sheds little light on Los Angeles and its ethnic groups. Basically, this is because the story of industrial decline has no ready parallel in Los Angeles (see Fainstein (1986) for a more general critique on the mismatch thesis as an explanation for the labour-market situation of African Americans). It is still unclear whether or not the concentration in areas really does exert an independent influence on the labour-market position of individuals. For example, although Schill (1992; see also Carter et al. in this issue) admits that the results of empirical research into the spatial mismatch hypothesis are not all consistent, he does contend that:

... the weight of the evidence supports the argument that the location of inner city poor households (...) creates a disadvan- tage for them in escaping poverty (Schill, 1992, p. 800).

On the basis of the same studies, however, Friedrichs (1997) concludes that the evidence presented on neighbourhood effects indicates a low or negligible impact and that most contexts can be explained by either individual or institutional effects or both.

Polarisation thesis. The essence of a polarised economy is the idea of the vanishing middle (Malecki, 1984; see also Roobeek, 1987; Scott and Storper, 1987). The shift to a service economy implies a growing demand for high- as well as low-status and low-wage jobs (Bailey and Waldinger, 1991). This shift might create employment opportunities for immigrants (Sassen, 1991). But it also points to the disappearance of a career ladder (Weiss, 1983) and an increase in junk jobs. Moreover, the creation of jobs requiring low skill levels also creates the demand for workers willing to take low-status, low-paying jobs, adding further to the demand for immigrant workers:

Thus, unlike the mismatch hypothesis, the restructuring hypothesis tells us that urban areas retain abundant, perhaps even increasing numbers of easy-entry jobs. The downside of the restructured metropolis is not the paucity of starting places, as in the mismatch view, but rather the absence of better jobs or developed mobility paths that would get the newcomers ahead (Waldinger and Bozorgmehr, 1996, p. 26).

Especially for those who are in the lower segments of the labour market, alternatives in the housing market may decline. Those who have low incomes and unsure expectancies in the labour market may have only limited choice of neighbourhoods to live in. In other words, the changing economy and the resulting new division of incomes may result in an increasing concentration of low-income groups, among them members of ethnic minorities. Whatever the kind of change, everybody seems to agree that things have changed in the economy, leading to 
... a new range of opportunities to certain regions and groups of people whilst simultaneously withdrawing pre-existing opportunities from others (Robinson, 1990a, p. 273).

Spatially, then, this 'new range of opportunities' might be translated into new configurations. This point will be elaborated in several contributions to this special issue.

\section{Demographic Developments}

The number of households looking for a home is an important variable. It must be taken into account when studying the housing market. Massive growth in the number of households within a relatively brief period may cause shortages if all those households are looking for the same kind of dwelling in the same area. Not only the number of households but also their composition should be taken into account, since some household types have specific preferences. For example, a rise in the number of extended families could boost the demand for large dwellings. Demographic developments may thus increase the competition between households. This can become a problem if more and more households are competing for the same kinds of dwellings within the local housing market.

Newcomers are often among the weakest parties in the competition for housing; they have a low income and little knowledge. Therefore, migrant labourers tend to settle in cheap residential areas in the poorer sections of the city, close to their place of work (Sarre et al., 1989, p. 7). This is especially true when they arrive without their families (Martin, 1991; Dieleman, 1992; van Kempen and Özüekren, 1997a). According to Peach (1968; quoted in Sarre et al., 1989), it is not that newcomers generally create a space for themselves; rather, they fill a vacuum. In this way, the choices of others are very important. Other people create vacancies in the existing stock and in particular neighbourhoods. Other people's choices often have to do with rising incomes and new additions to the housing stock (see also Herlyn, 1989).

\section{Political Developments}

Political developments affect rights and legislation. They may refer to gaining entry to a country (migration laws). Or they may concern rights to residency and work, social rights and political rights in the place of destination. In many countries, conflicts about these topics emerge for any number of reasons. Conflict may arise when immigrants are seen as competitors for housing, jobs and social benefits. Or they may be seen as a threat to the alleged cultural homogeneity of the indigenous population (Faist and Häußermann, 1996).

In some countries (such as Sweden and the Netherlands), immigrants have long had the right to vote in local elections. In other countries, the immigrants' participation in the political system may be much more restricted. Such differences might affect their integration into the host country and their positions in the housing and labour markets. Laws and regulations may even limit immigrants' opportunities directly (for example, the right to buy a dwelling or the right to occupy a unit in the social rented sector).

If immigrants are allowed to stay in a country for a limited time only, it is unlikely that they will invest in their residential situation.

It seems self-evident that only if immigrants have the assurance of being able to stay permanently in the country of residence will they be prepared to put down roots, to integrate fully into their new society, and to identify with it (Murray, 1995, p. 3).

The immigrants' legal status may also affect their housing preferences. Knowing they will have to return to their country of origin within a few years, they will not be interested in obtaining a permanent residence. Political developments in the country of origin may also be influential. According to Knerr (1990), the governments of Bangladesh and Pakistan have purposely promoted the export of their labour. In part, they have done so because of the resultant remittances. This 
policy also helps those governments to solve their problems of labour surplus. Of course, this policy is also directly related to the economic circumstances in the country of origin.

\section{The Future of Segregation}

By the late 1980s and early 1990s, evidence had been increasing of up-market moves by more affluent members of ethnic minorities. In some cases, moves from inner cities to suburbs had been detected (Robinson, 1990b; see also Daley in this issue). In other cases, moves from older and generally low-quality areas to newer areas with better housing were becoming a visible trend (as for the Turks in some west European countries; see Kesteloot et al., 1997; van Kempen, 1997). Owner-occupation became more common among the Turks in Germany (Glebe, 1997) and Belgium (Kesteloot et al., 1997). These moves from lower-quality to higher-quality housing and from rentals to owner-occupied dwellings generally also imply moves from one neighbourhood to another, thereby resulting in declining rates of segregation.

If these trends continue, we might expect a lower incidence of segregation and concentration in the future. However, we might also end up with spatial concentrations of those who cannot afford to move on. This picture is very clearly drawn by Wilson (1987) in his book The Truly Disadvantaged and more recently in his book entitled When Work Disappears (1996). This means that there might be a tendency in the direction of ethnic desegregation and deconcentration in many societies. But it also means that we will end up with a spatial concentration of the most marginalised groups in (urban) society.

Some people believe that segregation will not decline dramatically. The preference of many whites to live in (nearly) all-white neighbourhoods, the practice of racial steering by the real estate industry and other (urban) managers, the continuing low educational level of many immigrants and the declining number of suitable jobs, for instance, all contribute to the expectation that segre- gation and concentration will not decline substantially in the near future (see, for example, Farley, 1987; van Kempen and Özüekren, 1997b; and several contributions to this volume).

It is important to recognise that the position of ethnic minorities may differ greatly from one group to the next (see Phillips and Murdie and Borgegård in this issue). They may differ not only in housing conditions and spatial segregation but also in economic position. Cross (1992, p. 107), for example, showed that in Greater London, AfroCaribbeans are markedly underrepresented at the top of the class structure, whereas the distribution of South Asians is bimodal. Moreover, positions may change through time and may differ within groups, even between locations.

Finally, we should beware of applying American theories and situations uncritically to the European context. Despite all developments in the direction of more market influence and a decline in state influence, Europe still differs greatly in some respects from the US (see Goering, 1992; van Amersfoort, 1994; O'Loughlin and Friedrichs, 1996). First, the minority population in the US is much larger than that in west European countries. The larger numbers almost automatically generate spatial concentrations. Secondly, immigration to European countries is a much more recent phenomenon. This means that segregation existed much earlier in the US. Thirdly, in many west European countries, the share of social or public housing is much larger. Moreover, their social housing sector is not necessarily marginalised (Dieleman, 1992; Meusen and Van Kempen, 1995). Any comparison between the situation prevailing in America and in Europe-or, more specifically, between American blacks and European immigrants-is therefore dubious if not invalid.

\section{The Future of Research}

The topics of spatial segregation and concentration of ethnic groups have been studied for decades. Yet much more remains to be dis- 
covered. The point of departure for this special issue is that spatial segregation and concentration of ethnic groups should be studied in terms of contextual factors in addition to the traditional concern with individual factors and developments. The contextual (or aggregate) developments provide a framework within which preferences and resources of households and activities on the supply side of the housing market play a role. In that light, the research questions outlined below focus on these aspects.

- How do immigrants feel about segregation and concentration? Do they want to live in segregated areas? Or are they happier in mixed areas? Some research on these questions has been done. But studies of this type are mainly carried out at one point in time and at one location. Once the findings have been reported, the results tend to take on a life of their own. The findings are considered to be true, implying that preferences as well as the circumstances under which these preferences are formulated never change.

- Have immigrants been able to pursue a housing career and a concomitant 'spatial' career? Longitudinal data at the household level are necessary in order to answer this question. Such data would be very helpful in identifying preferences and barriers. Research in this area could suggest how possible barriers might be removed.

- How can the exact relations between the housing-market and labour-market positions of immigrants be identified? Have the relationships between these two markets been influenced by the governments of the west European welfare states? If so, is the retreat of government already having an impact? Is there, for example, a larger concentration of poor immigrant households in poor neighbourhoods than, say, five years ago? If so, is this concentration attributable to the effects of the declining welfare state? Or are other factors at play?

- How are segregation and concentration related to social exclusion? Does housing in general and its location in particular have independent negative effects on the extent and character of social exclusion? Can (adequate) housing help to prevent social exclusion? More specifically, how can the relation between social exclusion of immigrants, on the one hand, and housing, spatial concentration and segregation, on the other, be characterised in diverse urban regions? How can the mechanisms leading to these conditions be explained?

- Who are the successful immigrants in the housing market? How did they succeed in obtaining desirable housing conditions? Of course, their success is often a matter of income (see the paper by White in this issue). But which other factors could play a role?

- It might be interesting to study the probable effect on segregation of the acts of ethnic minority estate agents, or black-led housing associations. If they only have a small quantity of dwellings to allocate, the effect might be a larger concentration (see, for example, Phillips and Karn, 1992, p. 368). But this effect does not necessarily have to be negative. It might coincide with a better understanding of needs and better opportunities for specific groups in society (Harrison, 1992). What we definitely should not do is to make an automatic link between areas of deprivation and ethnicity. Eversley (1992, p. 142) states that ethnic minorities are not a necessary condition for the presence of deprivation. Although this might sound like a platitude, countless studies have been devoted to the classification of urban areas, using ethnicity as one of the indicators of deprivation.

\section{Notes}

1. Van Amersfoort's definition is a good one, except for the criterion that all members of the specific group must live in this area and none in other areas. A revised version of the definition makes sense; in the US, ghettos definitely exist, although some members of the specific group do not live there. They have managed to escape to other residential areas. However, desegregation does not 
mean that the ghetto and its characteristics have disappeared.

2. Originally, the term 'underclass' was intended as a purely economic concept, and this is how it was used in the 1960s and 1970s. Behavioural and spatial aspects were not included in the definition. The term was used "... to describe the chronically unemployed, underemployed, and underemployables being created by what we now call the post-industrial economy" (Gans, 1990, p. 271).

3. Others think that the association between the ghetto and the underclass "... is an idea insufficiently bounded ... to foreclose misinterpretation" (Hughes, 1989, p. 4).

4. The relation between contextual developments and individual behaviour refers to the theoretical problem of the relation between macro-developments and individual behaviour. Giddens (1984) and Coleman (1990) are two of the most important authors who tried to solve the problem of the relation between these two levels. It is, however, not the aim of this introductory article to review their work.

5. According to Logan and Swanstrom (1990, p. 9), economic restructuring is "an elusive concept with multiple meanings". They nonetheless identify three major themes that are common to most of the literature on this topic: a historical rupture (a radical break with the past, specifically since about 1973); priority of economic forces (which implies that economic relations are more basic than other relations); and "structure over agency" (which suggests that the processes of economic restructuring are independent of human will).

\section{References}

Adams, J. S. and Gilder, K. S. (1976) Household location and intra-urban migration, in: D. T. Herbert and R. J. Johnston (Eds) Social Areas in Cities, Volume 1: Spatial Processes and Form, pp. 159-192. London: Wiley.

Aldrich, H. E., Cater, J. C., Jones, T. P. and McEvoy, D. (1981) Business development and self-segregation: Asian enterprise in three British cities, in: C. PeACH, V. Robinson and S. Sмiтh (Eds) Ethnic Segregation in Cities, pp. 170-190. London: Croom Helm.

AMERSFOORT, H. VAN (1982) Immigration and the Formation of Minority Groups: The Dutch Experience 1945-1975. Cambridge: Cambridge University Press.

AMERSFoOrT, H. VAN (1994) Review of "Urban Housing Segregation of Minorities in Western
Europe and the United States", Ethnic and Racial Studies, 17, pp. 362-363.

Amersfoort, H. VAN and DE KLERK, L. (1987) The dynamics of immigrant settlement: Surinamese, Turks and Moroccans in Amsterdam 1973-1983, in: G. Glebe and J. O'Loughlin (Eds) Foreign Minorities in Continental European Cities, pp. 199-222. Stuttgart: Franz Steiner Verlag.

Amersfoort, J. M. M. VAN (1980) Woonsegregatie, gettovorming en de overheid, in: P. W. Blauw and C. PAstor (Eds) Soort bij soort: Beschouwingen over Ruimtelijke Segregatie als Maatschappelijk Probleem, pp. 113-138. Deventer: Van Loghum Slaterus.

BAILEY, T. and WALDINGER, R. (1991) The changing ethnic/racial division of labor, in: J. H. Mollenkopf and M. Castells (Eds) Dual City: Restructuring New York, pp. 43-78. New York: Russell Sage Foundation.

BALLARD, R. (1990) Migration and kinship: the differential effect of marriage rules on the processes of Punjabi migration to Britain, in: C. Clarke, C. Peach and S. Vertovec (Eds) South Asians Overseas: Migration and Ethnicity, pp. 219-249. Cambridge: Cambridge University Press.

Bassett, K. and Short, J. (1980) Housing and Residential Structure: Alternative Approaches. London: Routledge and Kegan Paul.

BAssett, K. and Short, J. (1989) Development and diversity in urban geography, in: D. GREGORY and R. WALFORD (Eds) Horizons in $\mathrm{Hu}$ man Geography, pp.175-193. London: Macmillan.

BeLL, W. (1953) The social areas of the San Francisco Bay region, American Sociological Review, 18, pp. 39-47.

BeLL, W. (1954) A probability model for the measurement of ecological segregation, Social Forces, 32, pp. 357-364.

BELL, W. (1968) The city, the suburb and a theory of social choice, in: S. GREer (Ed.) The New Urbanization, pp. 132-168. New York: St Martins.

Benevolo, L. (1980) The History of the City. London: Scholar Press.

Berry, B. J. L. and Kasarda, J. D. (1977) Contemporary Urban Ecology. New York: Macmillan.

Bhardwaj, S. M. and Rao, N. M. (1990) Asian Indians in the United States: a geographic appraisal, in: C. Clarke, C. Peach and S. VerTOVEC (Eds) South Asians Overseas: Migration and Ethnicity, pp. 197-217. Cambridge: Cambridge University Press.

Blanc, M. (1993) Housing segregation and the poor: new trends in French social rented housing, Housing Studies, 8, pp. 207-214.

BOAL, F. W. (1981) Ethnic residential segregation, 
ethnic mixing and resource conflict: a study in Belfast, Northern Ireland, in: C. PeACH, V. Robinson and S. Smith (Eds) Ethnic Segregation in Cities, pp. 235-251. London: Croom Helm.

Bolt, G. S. and van Kempen, R. (1997) Segregation and Turks' housing conditions in middle-sized Dutch cities, New Community, 23, pp. 363-384.

Bourdieu, P. (1979) La Distinction: Critique Sociale du Jugement. Paris: Editions de Minuit.

Bowes, A., McCluskey, J. and Sim, D. (1990) Ethnic minorities and council housing in Glasgow, New Community, 16, pp. 523-532.

Brown, L. A. and Moore, E. G. (1970) The intraurban migration process: a perspective, $G e$ ografiska Annaler, 52B, pp. 1-13.

Burgers, J. and ENGBERSEN, G. (1996) Globalisation, migration, and undocumented migrants, New Community, 22, pp. 619-635.

Burgers, J., van Kempen, R. and Bolt, G. S. (1997) Spatial Aspects of Social Exclusion. Paper for the COST-CIVITAS conference, Oslo, Norway, 5-7 June.

Burgess, E. W. (1925/1974) The growth of the city-an introduction to a research project, in: $\mathrm{R}$. E. Park, E. W. Burgess and R. D. McKenzie (Eds) The City, pp. 47-62. Chicago/London: University of Chicago Press.

Castells, M. (1977) The Urban Question: A Marxist Approach. London: Edward Arnold.

Castles, S. and Kosack, G. (1973) Immigrant Workers and Class Structure in Western Europe. London: Oxford University Press.

Cater, J. and Jones, T. (1987) Asian ethnicity and home-ownership, in: P. JACKSON (Ed.) Race and Racism: Essays in Social Geography, pp. 189-211. London: Allen and Unwin.

Clark, K. B. (1965) Dark Ghetto. New York: Harper and Row.

Clatrk, W. A. V. (1992) Residential preferences and residential choices in a multi-ethnic context, Demography, 29, pp. 351-466.

Clark, W. A. V. (1996) Residential patterns: avoidance, assimilation, and succession, in: R. W ALDINGER and M. BozorgmeHr (Eds) Ethnic Los Angeles, pp. 109-138. New York: Russell Sage Foundation.

Clark, W. A. V. and Dieleman, F. M. (1996) Households and Housing: Choice and Outcomes in the Housing Market. New Brunswick, NJ: Center for Urban Policy Research.

Clark, W. A. V., Deurloo, M. C. and Dieleman, F. M. (1986) Residential mobility in Dutch housing markets, Environment and Planning $A$, 18, pp. 763-788.

Clark, W. A. V., Deurloo, M. C. and Dieleman, F. M. (1997) Entry to home-ownership in Germany: some comparisons with the United States, Urban Studies, 34, pp. 7-19.
Coleman, J. S. (1990) The Foundations of Social Theory. Cambridge, MA: The Belknap Press of Harvard University Press.

Cross, M. (1992) Black workers, recession and economic restructuring in the West Midlands, in: M. Cross (Ed.) Ethnic Minorities and Industrial Change in Europe and North America, pp. 77-93. Cambridge: Cambridge University Press.

Dahya, B. (1974) The nature of Pakistani ethnicity in industrial cities in Britain, in: A. COHEN (Ed.) Urban Ethnicity, pp. 77-118. London: Tavistock.

DECKER, P. DE (1985) Naar een verklaringsmodel voor woonsegregatie, Planologische Diskussiebijdragen, pp. 297-310.

Denton, N. A. and Massey, D. S. (1991) Patterns of neighbourhood transition in a multiethnic world: U.S. metropolitan areas, 1970-1980, Demography, 28, pp. 41-63.

Dieleman, F. M. (1992) Multicultural Holland: myth or reality?, in: R. KING (Ed.) Mass Migration in Europe: The Legacy and the Future, pp. 118-135. London: Belhaven Press.

Duncan, O. D. and Duncan, B. (1955) Residential distribution and occupational stratification, American Journal of Sociology, 60, pp. 493503.

Engels, F. (1892/1980) The Condition of the Working Class in England. Moscow: Progress Publishers.

Eversley, D. (1992) Urban disadvantage and racial minorities in the UK, in: M. CROSS (Ed.) Ethnic Minorities and Industrial Change in Europe and North America, pp. 137-172. Cambridge: Cambridge University Press.

FAINSTEIN, N. (1986) The underclass/mismatch hypothesis as an explanation for black economic deprivation, Politics and Society, 15, pp. 403-451.

FAINSTEIN, N. (1993) Race, class and segregation: discourses about African Americans, International Journal of Urban and Regional Research, 17, pp. 384-403.

Faist, T. and Häubermann, H. (1996) Immigration, social citizenship and housing in Germany, International Journal of Urban and Regional Research, 20, pp. 83-98.

FARLEY, J. E. (1984) P*-segregation indices. What can they tell us about housing segregation in 1980?, Urban Studies, 21, pp. 331-336.

FARLEY, J. E. (1987) Segregation in 1980: how segregated are America's metropolitan areas?, in: G. A. Tobin (Ed.) Divided Neighborhoods; Changing Patterns of Racial Segregation, pp. 95-114. Newbury Park, CA: Sage Publications.

FARLEY, J. E. (1995) Race still matters; the minimal role of income and housing cost as causes 
of housing segregation in St. Louis, 1990, Ur ban Affairs Review, 31, pp. 244-254.

Firey, W. F. (1947) Land Use in Central Boston. Cambridge, MA: Harvard University Press.

FormAn, R. E. (1971) Black Ghettos, White Ghettos and Slums. Englewood Cliffs, NJ: Prentice Hall.

Forrest, R. and Williams, P. (1984) Commodification and housing: emerging issues and contradictions, Environment and Planning A, 16, pp. 1163-1180.

FRIEDRICHS, J. (1997) Do poor neighborhoods make their residents poorer? Context effects of poverty neighborhoods on residents, in: H.-J. Andress (Ed.) Empirical Poverty Research in a Comparative Perspective, pp. 77-99. Aldershot: Ashgate.

Gallie, D. (1994) Are the unemployed an underclass? Some evidence from the social change and economic life initiative, Sociology, 28, pp. 737-757.

Galster, G., Freiberg, F. and Houk, D. L. (1987) Racial differentials in real estate advertising practices: an exploratory case study, Journal of Urban Affairs, 9, pp. 199-215.

Gans, H. J. (1990) Deconstructing the underclass; the term's dangers as a planning concept, Journal of the American Planning Association, 56, pp. 217-277.

Giddens, A. (1984) The Constitution of Society: Outline of the Theory of Structuration. Cambridge: Polity Press.

Giffinger, R. and ReEger, U. (1997) Turks in Austria: backgrounds, geographical distribution and housing conditions, in: A. S. ÖZÜEKREN and R. VAn Kempen (Eds) Turks in European Cities: Housing and Urban Segregation, pp. 4166. Utrecht: European Research Centre on Migration and Ethnic Relations.

Glebe, G. (1997) Housing and segregation of Turks in Germany, in: A. S. ÖzÜEKREN and R. van Kempen (Eds) Turks in European Cities: Housing and Urban Segregation, pp. 122-157. Utrecht: European Research Centre on Migration and Ethnic Relations.

GoERING, J. (1992) Research note: race and public housing in Britain and the United States: notes for a policy relevant research agenda, New Community, 18, pp. 457-462.

Goldsmith, W. W. (1997) The metropolis and globalization: the dialectics of racial discrimination, deregulation, and urban form, American Behavioral Scientist, 41, pp. 299-310.

HADDON, R. (1970) A minority in a welfare state society: location of West Indians in the London housing market, New Atlantis, 2, pp. 80-123.

Hamnett, C. and Randolph, B. (1988) Cities, Housing and Profits: Flat Break-ups and the Decline of Private Renting. London: Hutchinson.
Hardoy, J. E. and Satterthwaite, D. (1989) Squatter Citizen: Life in the Urban Third World. London: Earthscan Publications.

Harris, C. D. and Ullman, E. L. (1945) The nature of cities, Annals of the American Academy of Political and Social Science, 242, pp. 717.

HARRIS, R. (1984) Residential segregation and class formation in the capitalist city: a review and directions for research, Progress in Human Geography, 8, pp. 26-49.

HARrison, M. L. (1992) Black-led housing organisations and the housing association movement, New Community, 18, pp. 427-437.

Henlyn, U. (1989) Upgrading and downgrading of urban areas, Tijdschrift voor Economische en Sociale Geografie, 80, pp. 97-105.

Hollingshead, A. B. (1947) A re-examination of ecological theory, Sociology and Social Research, 31, pp. 194-204.

HooimeiJer, P. and Linde, M. A. J. (1988) Vergrijzing, Individualisering en de Woningmarkt: het WODYN-Simulatiemodel. Utrecht: Geografisch Instituut, Rijksuniversiteit Utrecht.

Hoorn, F. J. J. H. van and van Ginkel, J. A. (1986) Racial leapfrogging in a controlled housing market: the case of the Mediterranean minority in Utrecht, the Netherlands, Tijdschrift voor Economische en Sociale Geografie, 77, pp. 187-196.

Hoyt, H. (1939) The Structure and Growth of Residential Neighborhoods in American Cities. Washington, DC: Federal Housing Administration.

HuFF, J. (1986) Geographic regularities in residential search behaviour, Annals of the Association of American Geographers, 76, pp. 208-227.

Hughes, M. A. (1989) Misspeaking truth to power: a geographical perspective on the 'underclass' fallacy. Paper for the 85th Annual Meeting of the Association of American Geographers, Baltimore, Maryland, 19-22 March.

Hughes, M. A. and Madden, J. F. (1991) Residential segregation and the economic status of black workers: new evidence for an old debate, Journal of Urban Economics, 29, pp. 28-49.

Jencks, C. (1992) Rethinking Social Policy: Race, Poverty, and the Underclass. Cambridge, MA: Harvard University Press.

Johnston, R. J., Gregory, D. and Smith, D. M. (1986) The Dictionary of Human Geography. Oxford: Basil Blackwell.

Jones, E. (1960) A Social Geography of Belfast. Oxford: Oxford University Press.

Jong, W. DE and Verkuyten, M. (1996) Urban renewal, housing policy and ethnic relations in Rotterdam, New Community, 22, pp. 689-705.

KARN, V. (1983) Race and housing in Britain: the role of the major institutions, in: N. GLAZER and 
K. Young (Eds) Ethnic Pluralism and Public Policy: Achieving Equality in the US and Britain, pp. 162-183. Lexington: Heath.

Karn, V., Kemeny, J. and Williams, P. (1985) Home Ownership in the Inner City: Salvation or Despair? Aldershot: Gower.

KASARDA, J. D. (1990) Structural factors affecting the location and timing of urban underclass growth, Urban Geography, 11, pp. 234-264.

Kasarda, J. D. (1993) Cities as places where people live and work: urban change and neighbourhood distress, in: H. G. Cisneros (Ed.) Interwoven Destinies: Cities and the Nation, pp. 81-124. New York: Norton.

Kasarda, J. D., Friedrichs, J. and Ehlers, K. E. (1992) Urban industrial restructuring and minority problems in the US and Germany, in: M. Cross (Ed.) Ethnic Minorities and Industrial Change in Europe and North America, pp. 250-275. Cambridge: Cambridge University Press.

Kemeny, J. (1987) Immigrant Housing Conditions in Urban Sweden. Gävle: The National Swedish Institute for Building Research.

KEMPEN, R. van (1997) Turks in the Netherlands: housing conditions and segregation in a developed welfare state, in: A. S. ÖZÜEKREN and R. VAN KEMPEN (Eds) Turks in European Cities: Housing and Urban Segregation, pp. 158-190. Utrecht: European Research Centre on Migration and Ethnic Relations.

Kempen, R. van and ÖzÜEKren, A. S. (1997a) Introduction, in: A. S. ÖZÜEKREN and R. VAN KeMPen (Eds) Turks in European Cities: Housing and Urban Segregation, pp. 1-11. Utrecht: European Research Centre on Migration and Ethnic Relations.

Kempen, R. van and ÖZüEkren, A. S. (1997b) Conclusion, in: A. Ş. ÖZÜEKREN and R. VAN Kempen (Eds) Turks in European Cities: Housing and Urban Segregation, pp. 248-261. Utrecht: European Research Centre on Migration and Ethnic Relations.

Kempen, R. VAN and VAN Weesep, J. (1991) Housing low-income households in Dutch cities, in: G. Saglamer and A. S. ÖzÜERren (Eds.) Housing for the Urban Poor, pp. b009b021. Istanbul: Istanbul Technical University.

Kempen, R. van and van Weesep, J. (1997) Segregation, housing and ethnicity in Dutch cities, Tijdschrift voor Economische en Sociale Geografie, 88, pp. 188-195.

Kesteloot, C. (1980) De Ruimtelijke Structuur van Brussel-Hoofdstad. Leuven: Acta Geographica Loveniensia.

Kesteloot, C., De Decker, P. and Manço, A. (1997) Turks and their housing conditions in Belgium, with special reference to Brussels, Ghent and Visé, in: A. Ș. ÖzÜEKREN and R. VAN Kempen (Eds) Turks in European Cities: Hous- ing and Urban Segregation, pp.67-97. Utrecht: European Research Centre on Migration and Ethnic Relations.

KNERR, B. (1990) South Asian countries as competitors on the world labour market, in: C. Clarke, C. Peach and S. Vertovec (Eds) South Asians Overseas: Migration and Ethnicity, pp. 173-196. Cambridge: Cambridge University Press.

Lieberson, S. (1981) An asymmetrical approach to segregation, in: C. PEACH, V. Robinson and S. Smith (Eds) Ethnic Segregation in Cities, pp. 61-82. London: Croom Helm.

LIPSKY, M. (1980) Street-level Bureaucracy: Dilemmas of the Individual in Public Services. New York: Russell Sage.

Logan, J. R. and Swanstrom, T. (1990) Urban restructuring: a critical view, in: J. R. LOGAN and T. Swanstrom (Eds) Beyond the City Limits: Urban Policy and Economic Restructuring in Comparative Perspective, pp. 3-24. Philadelphia: Temple University Press.

LundQVIST, L. J. (1992) Dislodging the Welfare State? Housing and Privatization in Four European Nations. Delft: Delft University Press.

MaLeCKI, E. J. (1984) High technology and local economic development, Journal of the American Planning Association, 50, pp. 262-269.

Marcuse, P. (1997) The ghetto of exclusion and the fortified enclave: new patterns in the United States, American Behavioral Scientist, 41, pp. 311-326.

Martin, P. L. (1991) The Unfinished Story: Turkish Labour Migration to Western Europe. Geneva: International Labour Office.

Massey, D. S. and Denton, N. A. (1993) American Apartheid and the Making of the Underclass. Cambridge, MA: Harvard University Press.

McKenzie, R. D. (1925/1974) The ecological approach to the study of the human community, in: R. E. Park, E. W. Burgess and R. D. McKenzie (Eds) The City, pp. 63-79. Chicago/ London: University of Chicago Press.

Meusen, H. and van Kempen, R. (1995) Towards residual housing? A comparison of Britain and the Netherlands, Netherlands Journal of Housing and the Built Environment, 10, pp. 239258.

Morris, L. D. (1987) Local social polarization: a case study of Hartlepool, International Journal of Urban and Regional Research, 11, pp. 331350 .

Morris, L. D. (1993) Is there a British underclass?, International Journal of Urban and Regional Research, 17, pp. 404-412.

Mullings, B. (1992) Investing in public housing and racial discrimination: implications in the 1990s, New Community, 18, pp. 415-425. 
Murdie, R. A. (1969) Factorial Ecology of Metropolitan Toronto 1951-1961. Chicago: University of Chicago Press.

Murie, A. and Musterd, S. (1996) Social segregation, housing tenure and social change in Dutch cities in the late 1980s, Urban Studies, 33, pp. 495-516.

Murray, J. (1995) Keynote Address. Paper for the Seminario Europeo Vivienda e Integración Social de los Inmigrantes, Barcelona, 23-25 October.

O'Loughlin, J. (1987) Chicago an der Ruhr or what?, in: G. GLeBE and J. O'Loughlin (Eds) Foreign Minorities in Continental European Cities, pp. 52-69. Stuttgart: Franz Steiner Verlag.

O'Loughlin, J. and Friedrichs, J. (1996) Polarization in post-industrial societies: social and economic roots and consequences, in: $\mathrm{J}$. O'Loughlin and J. Friedrichs (Eds) Social Polarization in Post-industrial Metropolises, pp. 1-18. Berlin/New York: De Gruyter.

ÖZÜEKREN, A. Ș. (1992) Turkish Immigrant Housing in Sweden: An Evaluation of Housing Conditions in a Stockholm Suburb. Gävle: The National Swedish Institute for Building Research.

ÖZüEKren, A. S. and MAgnusson, L. (1997) Housing conditions of Turks in Sweden, in: A. Ş. ÖZÜEKREN and R. VAn KemPen (Eds) Turks in European Cities: Housing and Urban Segregation, pp. 191-222. Utrecht: European Research Centre on Migration and Ethnic Relations.

ÖzǗnRen, A. S. and van Kempen, R. (1997) Explaining housing conditions and housing market positions, in: A. SS. ÖZÜEKREN and R. VAN KeMPen (Eds) Turks in European Cities: Housing and Urban Segregation, pp. 12-29. Utrecht: European Research Centre on Migration and Ethnic Relations.

PAHL, R. (1975) Whose City? Harmondsworth: Penguin.

PAHL, R. (1977) Managers, technical experts and the state, in: M. Harloe (Ed.) Captive Cities, pp. 49-60. London: John Wiley.

PARK, R. E. (1925/1974) The city: suggestions for the investigation of human behavior in the urban environment, in: R. E. PARK, E. W. Burgess and R. D. McKenzie (Eds) The City, pp. 1-46. Chicago: Chicago University Press.

Park, R. E., Burgess, E. W. and McKenzie, R. D. (Eds) (1925/1974) The City. Chicago: Chicago University Press.

Peach, C. (1968) West Indian Migration to Britain: A Social Geography. London: Oxford University Press.

Peach, C. (1975) Urban Social Segregation. London: Longman.

Peach, C. (1981) Conflicting interpretations of segregation, in: P. JACKSON and S. SMITH (Eds) Social Interaction and Ethnic Segregation, pp. 19-33. London: Academic Press.

PEACH, C. (1984) The force of West Indian island identity in Britain, in: C. Clarke, D. LeY and C. PeACH (Eds) Geography and Ethnic Pluralism, pp. 214-230. London: Allen and Unwin.

Peach, C. (1991) Review of "Ethnic Minority Housing: Explanations and Policies", Housing Studies, 6, pp. 73-76.

PEACH, C. (1992) Urban concentration and segregation in Europe since 1945, in: M. Cross (Ed.) Ethnic Minorities and Industrial Change in Europe and North America, pp. 113-136. Cambridge: Cambridge University Press.

Peach, C. and Smith, S. (1981) Introduction, in: C. Peach, V. Robinson and S. Smith (Eds) Ethnic Segregation in Cities, pp. 9-22. London: Croom Helm Ltd.

Phillips, D. and Karn, V. (1992) Race and housing in a property owning democracy, New Community, 18, pp. 355-369.

Portes, A. and Sensenbrenner, J. (1993) Embeddedness and immigration: notes on the social determinants of economic action, American Journal of Sociology, 98, pp. 1320-1350.

Portes, A. and Zhou, M. (1996) Self-employment and the earnings of immigrants, American Sociological Review, 61, pp. 219-239.

REX, J. (1968) The sociology of a zone of transition, in: R. E. PAHL (Ed.) Readings in Urban Sociology, pp. 211-231. London: Pergamom.

Rex, J. and Moore, R. (1967) Race, Community and Conflict. London: Oxford University Press.

ReX, J. and Tombinson, S. (1979) Colonial Immigrants in a British City: A Class Analysis. London: Routledge and Kegan Paul.

Robinson, V. (1981) The development of South Asian settlement in Britain and the myth of return, in: C. PeACH, V. Robinson and S. Smith (Eds) Ethnic Segregation in Cities, pp. 149169. London: Croom Helm.

Robinson, V. (1986) Transients, Settlers and Refugees: Asians in Britain. Oxford: Clarendon Press.

Robinson, V. (1990a) Boom and gloom: the success and failure of South Asians in Britain, in: C. Clarke, C. Peach and S. Vertovec (Eds) South Asians Overseas: Migration and Ethnicity, pp. 269-296. Cambridge: Cambridge University Press.

Robinson, V. (1990b) Roots to mobility: the social mobility of Britain's black population 1971-1987, Ethnic and Racial Studies, 13, pp. 274-286.

RobSon, B. T. (1969) Urban Analysis. Cambridge: Cambridge University Press.

Roobeek, A. (1987) The crisis in Fordism and the rise of a new technological paradigm, Futures, April, pp. 129-154. 
Rossi, P. H. (1955) Why Families Move: A Study in the Social Psychology of Urban Residential Mobility. Glencoe: Free Press.

Sanders, J. M. and Nee, V. (1996) Immigrant self-employment: the family as social capital and the value of human capital, American Sociological Review, 61, pp. 231-249.

SARKISSIAN, W. (1976) The idea of social mix in town planning, Urban Studies, 13, pp. 231246.

Sarre, P., Phillips, D. and Skellington, R. (1989) Ethnic Minority Housing: Explanations and Policies. Aldershot: Avebury.

SASSEN, S. (1990) Economic restructuring and the American city, Annual Review of Sociology, 16, pp. 465-490.

Sassen, S. (1991) The Global City: New York, London, Tokyo. Princeton, NJ: Princeton University Press.

Saunders, P. (1979) Urban Politics: A Sociological Interpretation. London: Hutchinson.

SchiLl, M. H. (1992) Deconcentrating the inner city poor, Chicago-Kent Law Review, 67, pp. 795-853.

ScotT, A. J. and Storper, M. (1987) High technology industry and regional development: a theoretical critique and reconstruction, International Social Science Journal, 112, pp. 215232.

Sennett, R. (1970) The Uses of Disorder. New York: Vintage.

Sheppard, E. (1990) Ecological analysis of the 'urban underclass': commentary on Hughes, Kasarda, and O'Regan and Wiseman, Urban Geography, 11, pp. 285-297.

Shevky, E. and Bell, W. (1955) Social Area Analysis. Stanford, CA: Stanford University Press.

Shevky, E. and Williams, M. (1949) The Social Areas of Los Angeles. Los Angeles: University of California Press.

SiKsiö, O. and Borgeg ̊̊Rd, L. E. (1990) Markets in distress: on access to housing in local housing markets. Paper for the 7th Meeting of the CIB Working Commission W69 Housing Sociology, The National Swedish Institute for Building Research, Gävle.

Sмiтh, D. J. (1977) Racial Disadvantage in Britain. Harmondsworth: Penguin.

Speare, A., Goldstein, S. and Frey, W. H. (1975) Residential Mobility, Migration and Metropolitan Change. Cambridge, MA: Ballinger.

Stapleton, C. M. (1980) Reformulation of the family life-cycle concept: implications for residential mobility, Environment and Planning A, 12, pp. 1103-1118.

Taueber, K. E. and Taueber, A. F. (1965) Negroes in Cities. Chicago: Adline.

TeIXeIRA, C. (1995) Ethnicity, housing search, and the role of the real estate agent: a study of
Portuguese and non-Portuguese real estate agents in Toronto, Professional Geographer, 47, pp. 176-183.

Timms, D. W. G. (1971) The Urban Mosaic: Towards a Theory of Residential Differentiation. Cambridge: Cambridge University Press.

Tombins, R. (1997) Officer discretion and minority ethnic housing provision, Netherlands Journal of Housing and the Built Environment, 12, pp. 179-197.

Turner, M. A. and Wienk, R. (1993) The persistence of segregation in urban areas: contributing causes, in: G. T. KINGSLEY and M. A. TURNER (Eds) Housing Markets and Residential Mobility, pp. 193-216. Washington, DC: Urban Institute.

Wacquant, L. J. D. (1996) The rise of advanced marginality: notes on its nature and implications, Acta Sociologica, 39, pp. 121-139.

Wacquant, L. J. D. (1998) Negative social capital: state breakdown and social destitution in America's urban core, Netherlands Journal of Housing and the Built Environment, 13, pp. 25-40.

Wacquant, L. D. J. and Wilson, W. J. (1993) The cost of racial and class exclusion in the inner city, in: W. J. WILSON (Ed.) The Cost of Racial and Class Exclusion in the Inner City, pp. 25-42. Newbury Park, CA: Sage.

WALdinger, R. and Bozorgmehr, M. (1996) The making of a multicultural metropolis, in: R. W ALDINGER and M. BozorgmeHR (Eds) Ethnic Los Angeles, pp. 3-37. New York: Russell Sage Foundation.

WARD, R. and Sims, R. (1981) Social status, the market and ethnic segregation, in: C. PEACH, V. Robinson and S. SMITH (Eds) Ethnic Segregation in Cities, pp. 217-234. London: Croom Helm.

WARF, B. (1989) Deindustrialization, service sector growth, and the underclass in the New York Metropolitan Region. Paper for the 85th Annual Meeting of the Association of American Geographers, Baltimore, Maryland, 19-22 March.

WeEsep, J. VAN (1984) Condominium conversion in Amsterdam: boon or burden? Urban Geography, 5, pp. 165-177.

WeISS, M. A. (1983) High-technology industries and the future of employment, Built Environment, 9, pp. 51-60.

White, P. (1987) The migrant experience in Paris, in: G. Glebe and J. O'Loughlin (Eds) Foreign Minorities in Continental European Cities, pp. 184-198. Stuttgart: Franz Steiner Verlag.

WILson, K. and Portes, A. (1981) Immigrant enclaves: an analysis of the labor market experiences of Cubans in Miami, American Journal of Sociology, 86, pp. 295-319.

WILSON, W. J. (1987) The Truly Disadvantaged: The Inner City, the Underclass, and Public 
Policy. Chicago: The University of Chicago Press.

WILson, W. J. (1991) Studying inner-city dislocations, American Sociological Review, 56, pp. $1-14$.

WILSON, W. J. (1996) When Work Disappears: The World of the New Urban Poor. New York: Alfred Knopf.

WIPPLER, R. (1990) Cultural resources and participation in high culture, in: M. HeChTER, K. D. OPP and R. WIPPleR (Eds) Social Institutions: Their Emergence, Maintenance and Effects, pp. 187-204. Berlin: De Gruyter.

WIRTH, L. (1928) The Ghetto. Chicago: University of Chicago Press.
WirTh, L. (1944) Human ecology, American Journal of Sociology, 50, pp. 483-488.

WOLPERT, J. (1965) Behavioral aspects of the decision to migrate, Papers and Readings of the Regional Science Association, 15, pp. 159169.

Woods, R. I. (1976) Aspects of the scale problem in the calculation of segregation indices: London and Birmingham, 1961 and 1971, Tijdschrift voor Economische en Sociale Geografie, 67, pp. 169-174.

Yeates, M. H. (1989) The North-American City. New York: Harper and Row.

Zorbaugh, H. W. (1929) The Gold Coast and the Slum. Chicago: University of Chicago Press. 
Copyright of Urban Studies is the property of Carfax Publishing Company and its content may not be copied or emailed to multiple sites or posted to a listserv without the copyright holder's express written permission. However, users may print, download, or email articles for individual use. 